\title{
Labor editorial del Instituto durante diez años
}

El día 6 de septiembre del corriente año se ha cumplido el décimo aniversario de la creación del Instituto de Estudios de Administración Local, realizada por Ley de 6 de septiembre de r940.

La importancia de la efemérides en la Administración Local española es tal, que consideramos no debe dejarse pasar inadvertida tal fecha, siquiera, por imperio de las necesidades materiales, el Instituto no empezara a funcionar, de hecho, hasta unos meses después.

Sabido es que la Ley Municipal de 3I de octubre de 1935 lo que preconizó fué simplemente la creación de una Escuela Nacional de Funcionarios de la Administración Local, no un Centro tan amplio como el que la Ley de 6 de septiembre citada plasmó, y en el que la Escuela Nacional de Administración y Estudios Urbanos constituye tan sólo una de sus tres Secciones básicas.

De las otras dos, Estadística e Investigación, y Biblioteca, Documentación y Publicaciones, vamos a reférirnos únicamente en este estudio a la última de ellas, considerando la ingente labor que desde la publicación de la Ley, más concretamente en diez años escasos, ha realizado el Instituto como Organismo oficial al que el Estado ha conferido la misión de propulsar las publicaciones de interés para la Administración local, è su más amplia concepción, al margen de especulaciones comerciales y con una. finalidad esencialmente pública.

Los Secretarios e Interventores de Administración local procedentes de las primeras promociones salidas a raíz de la implan- 
tación de los Estatutos municipal y provincial de 1924 y 1925 , respectivamente, y especialmente los funcionarios procedentes del anterior sistema de habilitación, conocieron y recuerdan las enormes dificultades de documentación y estudio con que se tropezaba en aquellos tiempos por los funcionarios locales, especialmente los desplazados en alejados pueblos, donde no podían cambiarse impresiones ni confiar las dudas a un compañero, y dada la carencia casi absoluta de textos sobre. Administración local.

El Instituto de Estudios ha tenido la gran virtualidad, en este aspecto, de despertar un interés creciente por los temas del Derecho de los Entidades locales (rebasada ya la antigua denominación de "lo Municipal» por "lo Local», como concepto más amplio. que abarca Municipios y Provincias), y al lado de su gran número de títulos (unos sesenta actualmente), han surgido multitud de ediciones particulares, de mayor o menor interés, pero útiles en su inmensa mayoría, alentados, sin duda, sus autores, por el ejemplo oficial.

Claro que la mayoría de las publicaciones del Instituto están específicamente vinculadas al nombre de un autor, al lado de otras que representan el trabajo de Seminario de sus Secciones específicas y de su competente grupo de Becarios.

Paralelamente a la publicación de libros apareció, en primero de enero de I942, el número uno de la "Revista de Estudios de la Vida.Local", órgano bimestral del Instituto, que se ha seguido publicando sin interrupción y del que en esta fecha van publicados cincuenta y dos números, muchos de cuyos trabajos han sído objeto de separatas.

La primera publicación específica editada por el Instituto tienc la fecha del año 1942 y bajo el título de "Administración provincial española. Sus problemas"; recoge una serie de conferencias pronunciadas en la cátedra Valdecilla, de la Universidad Central, por el señor Gascón y Marín, Catedrático de la misma y Jefe de la Sección de Publicaciones idel Instituto. La última publicación. de recientísima aparición, es el libro del Magistrado del Tribunal Supremo, señor Castejón, denominado “Faltas penales, gubernativas $\mathrm{y}$ administrativas". 
Algunas de las obras publicadas responden a un plan de serie, bajo distintas rúbricas de especialísimo interés, como Estadistica, Haciendas locales, Urbanismo, Obras históricas, Legislación y Jurisprudencia, etc., etc.

La existencia de estas series, amplias y varias, de publicaciones sobre la vida local española, monográficas la mayoría de ellas, ha provocado también en gran escala el interés de las Corporaciones locales por la creación de Bibliotecas técnicas (de las que los libros del Instituto constituyen el principal núcleo), al servicio de sus funcionarios, y cuyo manejo frecuente ha de traducirse, sin duda, en beneficios indudables para la marcha administrativa de tales Corporaciones, al tener aquellos funcionarios medios, cada vez más amplios, de contrastar criterios, de evitar erro. res y de actualizar y completar constantemente sus conocimientos.

Es especialmente interesante el considerable número de Secretarios de Administración Local, Licenciados en Derecho, que a la sombra de todos aquellos estímulos y en un notorio deseo de superación y de prestigio profesional, vienen realizando los estudios del Doctorado en IDerecho, singularmente acogidos al amoroso clima de estudio de la Biblioteca especializada dei Instituto, que ya conoce en sus largas jornadas silenciosas, del sondo afán de unos hombres estimulados por la existencia del Centro, que tantas luces de prestigio ha venido a añadir a los ya logrados Cuerpos de la Administración Local española.

\section{Alberto Gallego y Burín}

